\title{
Bağımsız Denetim Sürecinin Covid-19 Salgınının Etkileri Açısından Değerlendirilmesi (Evaluation of Independent Audit Process in terms of Effects of Covid-19 Pandemic)
}

\section{Burak Ali ADANA iD a Mehmet ÖZBİRECİKLi iD}

a Mustafa Kemal Üniversitesi, İktisadi ve İdari Bilimler Fakültesi, Hatay, Türkiye. burakaliadana@gmail.com

b Mustafa Kemal Üniversitesi, İktisadi ve İdari Bilimler Fakültesi, Hatay, Türkiye. mozbirecikli@yahoo.com

\begin{tabular}{|c|c|}
\hline MAKALE BİLGİSİ & ÖZET \\
\hline $\begin{array}{l}\text { Anahtar Kelimeler: } \\
\text { Bağımsız Denetim } \\
\text { Covid-19 } \\
\text { Koronavirüs } \\
\text { Denetçi Raporu } \\
\text { Kilit Denetim Konuları }\end{array}$ & $\begin{array}{l}\text { Amaç - } 2019 \text { yılının Aralık ayında Çin Halk Cumhuriyeti'nin Vuhan eyaletinde ortaya çıkan ve daha } \\
\text { sonra hızla yayılarak tüm dünyayı etkisi altına alan Covid-19 salginının (SARS-CoV-19), toplumsal } \\
\text { hayata, ülkelerin ekonomilerine ve işletmelerin faaliyetlerine etkileri çok ciddi şekilde } \\
\text { hissedilmektedir. Covid-19'un, birçok alanı etkilediği gibi bağımsız denetime tabi işletmelerin } \\
\text { bağımsız denetim süreçlerini de etkilemesi söz konusudur. Bu çalışmanın amacı Covid-19 } \\
\text { salgınının, bağımsız denetim sürecine ve bu sürecin çıktısı olan bağımsız denetçi raporu üzerindeki } \\
\text { potansiyel etkilerini tartışma konusu ederek içinde bulunduğumuz süreçte bağımsız denetim } \\
\text { faaliyetini sürdüren denetim mesleği mensuplarının faaliyetlerine katkı sağlamaktır. }\end{array}$ \\
\hline $\begin{array}{l}\text { Gönderilme Tarihi } 17 \text { Nisan } \\
2020 \\
\text { Revizyon Tarihi } 12 \text { Haziran } \\
2020 \\
\text { Kabul Tarihi } 20 \text { Haziran } 2020\end{array}$ & $\begin{array}{l}\text { Yöntem - Mevcut ve potansiyel etkiler, bağımsız denetim süreci ve Bağımsız Denetim } \\
\text { Standartlarının (BDS) gereklilikleri açısından değerlendirilmiş ve bağımsız denetime tabi şirketlerin } \\
\text { www.kap.org.tr ve www.spk.gov.tr internet sitelerinde yayımlanan bağımsız denetçi raporlarında } \\
\text { Covid-19 salgınının etkilerine nasıl yer verildiği inceleme konusu edilmiştir. Bunun için sosyal } \\
\text { bilimlerde nitel araştırma yöntemlerinden biri olan dökümantasyon tarama yöntemi kullanılmıştır. } \\
\text { İnceleme tarihi (04.06.2020) itibariyle yayımlanmış denetçi raporlarının tümü (81 rapor) ana kütle } \\
\text { olarak alınmış ve incelenmiştir. }\end{array}$ \\
\hline & $\begin{array}{l}\text { Bulgular - Mevcut ve potansiyel etkiler dikkate alındığında, Covid-19 salgınının, bağımsız denetim } \\
\text { sürecine önemli etkileri olduğu ve bağımsız denetçilerin denetim sürecini planlarken ve denetçi } \\
\text { raporunu hazırlarken bu etkileri dikkate alması gerektiği görülmektedir. }\end{array}$ \\
\hline $\begin{array}{l}\text { Makale Kategorisi: } \\
\text { Araştırma Makalesi }\end{array}$ & $\begin{array}{l}\text { Tartışma - Salgının, denetimin planlanması ve yürütülmesi, fiziksel kanıt toplama ve bağımsız } \\
\text { denetim sürecine önemli etkileri olduğu görülmektedir. Bu nedenle bağımsız denetçilerin denetim } \\
\text { riskini düşürmek için denetim sürecini bu duruma uygun bir yaklaşımla planlaması ve denetçi } \\
\text { raporunu hazırlarken bu etkileri raporuna yansıtması gerekir. }\end{array}$ \\
\hline
\end{tabular}

\begin{tabular}{|c|c|}
\hline ARTICLE INFO & ABSTRACT \\
\hline Keywords: & \multirow{7}{*}{$\begin{array}{l}\text { Purpose - The coronavirus pandemic (Covid-19), which emerged in the Wuhan province of the } \\
\text { People's Republic of China in December } 2019 \text { and later has spread rapidly to the whole world, has a } \\
\text { serious impact on life of people, economy of countries and activity of businesses. It is inevitable that } \\
\text { coronavirus pandemic affects the independent audit processes of businesses as well as many other } \\
\text { fields. This study aims to provide contribution with independent auditors who have conducted } \\
\text { audit activities nowadays by dicussing the current and potential effects of the coronavirus on the } \\
\text { independent audit process and the independent audit report that is the output of this process. }\end{array}$} \\
\hline Independent Audit & \\
\hline Covid 19 & \\
\hline Covid-19 & \\
\hline Coronavirüs & \\
\hline Auditor's Report & \\
\hline Kev Audit & \\
\hline & \multirow{4}{*}{$\begin{array}{l}\text { Design/methodology/approach - The current and potential effects were evaluated in terms of } \\
\text { independent audit process and requirements of International Standard on Auditing (ISA) and } \\
\text { examined to what extent auditors draw attention the said effects in the independent audit reports of } \\
\text { the companies subject to independent audit published on the websites www.kap.org.tr and } \\
\text { www.spk.gov.tr. To do this, document examination method which is one of the qualitative research } \\
\text { methods in social sciences is used. The universe used in the study is whole auditor's reports ( } 81 \\
\text { reports) issued as of the date of investigation made for the study. }\end{array}$} \\
\hline Received 17 April 2020 & \\
\hline Revised 12 June 2020 & \\
\hline Accepted 20 June 2020 & \\
\hline Article Classification: & $\begin{array}{l}\text { Findings - Given the current and potential effects, it is seen that coronavirus has serious effects on } \\
\text { independent audit process and independent auditors must consider the said effects while planning } \\
\text { audit process and preparing auditor's report. }\end{array}$ \\
\hline Research Article & $\begin{array}{l}\text { Discussion - It is seen that covid-19 pandemic has important effects on audit's planning and } \\
\text { practicing, collecting physical evidence and independent audit process. Therefore, in order to reduce } \\
\text { the audit risk, independent auditors should plan the audit process in accordance with this situation } \\
\text { and reflect these effects on their report when preparing their "auditor's report". }\end{array}$ \\
\hline
\end{tabular}




\section{GİRIŞ}

Dünyada hızla yayılan ve Dünya Sağlık Örgütü (DSÖ) tarafından pandemi (salgın) olarak ilan edilen Covid19'un (koronavirüs) insan sağlığına etkilerini azaltmak adına hükümetler, hem DSÖ hem de diğer bilimsel kurulların görüşleri doğrultusunda çeşitli önlemler almaktadır. Covid-19'un insan sağlığına etkilerinin yanında üretim, tüketim, ticaret ve ulaşım gibi birçok açıdan ekonomik ve sosyal etkileri bulunmaktadır.

Söz konusu ekonomik etkiler işletmelerin yapısına, teknolojik olanaklarına, müşteri kitlesinin özelliklerine ve iş sürecinin niteliğine göre değişiklik göstermektedir. Nitekim bu salgın sürecinde internetten satış yapan işletmeler ve kargo firmalarının avantaj sağladığı, taşıma, konaklama, eğlence sektöründeki işletmelerin ise zor duruma düştügü görülmektedir. Salgının bağımsız denetim mesleğine olan etkileri açısından bakıldığında salgın sürecinin bağımsız denetim faaliyetlerini ve sürecini de ciddi anlamda etkilediği görülmektedir.

Covid-19 salgınının, denetim sözleşmesinin kabulü, denetimin planlanması, denetim ekibinin oluşturulması, kilit denetim konularının belirlenmesi ve kanıt toplama gibi bağımsız denetim sürecinin önemli aşamalarını etkilediği görülmektedir.

Bu çalışmanın amacı Covid-19 salgınının, bağımsız denetim sürecine ve bu sürecin çıktısı olan bağımsız denetçi raporu üzerindeki potansiyel etkilerini tartışma konusu ederek içinde bulunduğumuz süreçte bağımsız denetim faaliyetini sürdüren bağımsız denetim mesleği mensuplarının faaliyetlerine katkı sağlamaktır.

Çalışmada Covid-19 salgınının denetim sürecine olası etkileri bağımsız denetimin olağanüstü olaylarla ilgili aşama ve başlıkları bağlamında tartışma konusu edilmektedir. Aynı zamanda Covid-19 salgınından etkilenen denetim aşamaları, ilgili Bağımsız Denetim Standartları (BDS) çerçevesinde değerlendirilmiş ve mevcut veya potansiyel etkilere karşı alınabilecek tedbirlere yer verilmiştir.

\section{YÖNTEM}

Çalışmada araştırma konusu edilecek olan denetçi raporlarında Covid-19 ile ilgili mevcut ve potansiyel etkilerle ilgili açılamaların içeriğinin ortaya konulması ve Bağımsız Denetim Standartlarının (BDS) gereklilikleri açısından değerlendirilmesi amacıyla sosyal bilimlerde nitel araştırma yöntemlerinden biri olan dökümantasyon tarama yöntemi ile yine nitel araştırma yöntemlerinden biri olan keşifsel araştırma modeli olarak İkincil Kaynaklardan Veri Toplanması yöntemi kullanılmıştır. Böylece bağımsız denetçi raporlarının içerikleri, BDS'ler çerçevesinde Covid-19'un etkilerine yer verilmesi açısından inceleme konusu edilerek denetim süreçlerinin yerindeliği tartışma konusu edilmektedir.

İnceleme tarihi itibariyle bağımsız denetime tabi şirketlerin www.kap.org.tr ve www.spk.gov.tr internet sitelerinde yayımlanmış olan 81 denetçi raporunun tümü ana kütle olarak alınmıştır. Şöyle ki Mart ayının bitimiyle beraber şirketler, 1. çeyrek (01.01.2020 - 31.03.2020) finansal raporlarını yayımlamaya başlamaktadır. $\mathrm{Bu}$ raporların çoğu, bir bağımsız denetim firması tarafından onaylanmamış şekilde yayımlanmaktadır. Çalışmanın amacı Covid-19'un bağımsız denetim sürecine etkilerini incelemek olduğundan bağımsız denetimden geçmemiş finansal raporlar elenerek çalışma dişında bırakılmıştır. Bu sebeple 13.03.2020 ve 04.06.2020 tarihleri arasında www.kap.org.tr ve www.spk.gov.tr internet sitelerinde yayımlanan tüm finansal raporlar incelenmiş ve bunlardan bağımsız denetçi raporu içerenler çalışmanın ana kütlesini oluşturmuştur.

\section{BULGULAR}

\subsection{Bağımsız Denetim Sürecinde Covid-19 Salgınından Etkilenen Denetim Aşamaları}

\subsubsection{Yeni Denetim Sözleşmesinin Kabulï}

Bağımsız denetçilerin yeni işletme kabul ederken uyguladıkları bazı prosedürler bulunmaktadır. İçinde bulunduğumuz salgın sürecine yönelik alınan; seyahat etmenin ve ofis gibi kalabalık ortamlarda bulunmanın kısıtlanması gibi önlemler bu prosedürlerin uygulanmasını zorlaştırmaktadır. Örneğin kabul sürecinin başlıca uygulamalarından olan; bir önceki denetçiyle görüşme ve denetçinin çalışmalarını inceleme süreci neredeyse mümkün olamayacaktır. Bu ve bunun gibi sebeplerden dolayı denetçi, işi kabul edip etmeyeceğini değerlendirirken eskiye nazaran dijital yolları daha çok kullanarak kaynaklara ulaşmaya çalışacaktır. Diğer taraftan denetçi, salgın sürecinin neden olabileceği aksaklıkları göz önüne alarak müşteriye bazı gecikmelerin yaşanabileceği konusunda bilgi vermelidir ("Covid-19 Salgınının", 2020). 


\subsubsection{Denetimin Planlanması ve Risk Değerlendirme Süreci}

Covid-19'un yarattığı olağanüstü ortamın bir sonucu olarak denetçinin, denetim planlamasında ve risk değerlendirme sürecinde bazı değişiklikler yapması gerekebilir. Covid-19'un etkilerinin sürekli olarak değişmesi, denetçinin denetim planını ve risk değerlendirme sürecinde önemli yanlışlık riski değerlendirmelerini devamlı gözden geçirmesini ve ihtiyaç duyduğu durumlarda revize etmesini gerektirmektedir. İçinde bulunduğumuz salgın ortamı gibi istikrarsız ortamlarda, işletmelerin oluşturdukları iç kontrol sistemleri istenilen düzeyde etkin olamayabilir. Denetçinin bu durumu göz önüne alarak iç kontrol sisteminde yaşanacak aksaklıklardan dolayı oluşabilecek hata ve hile kaynaklı önemli yanlışlık riskinde artış olup olmadığını saptamak için ilave denetim prosedürleri uygulayıp uygulamayacağına karar vermesi gerekebilir ("Covid-19 Salgınının", 2020; Türkiye Serbest Muhasebeci Mali Müşavirler ve Yeminli Mali Müşavirler Odaları Birliği [TÜRMOB], 2020).

\subsection{3. Önemlilik}

Bağımsız denetim sürecinde, denetçinin temel amaçlarından biri de; finansal tabloların bütününü etkileyen hata veya hile kaynaklı önemli bir yanlışlığın mevcut olup olmadığına ilişkin makul güvence elde etmektir. Denetçinin, makul güvence elde etme yolundaki en mühim araçlarından biri "önemlilik seviyesi"dir. Önemlilik seviyesi, makul bir bilgi kullanıcısının kararını etkilemeyen maksimum yanlışlık miktarıdır. Bağımsız denetimde önemlilik kavramı; finansal tablolardaki eksik veya yanlış raporlamaların, bilgi kullanıcılarının alacakları kararları etkilemesi makul derecede bekleniyorsa, bu eksik veya yanlışların önemli olarak değerlendirilmesi şeklinde ifade edilmektedir (Selimoğlu, Özbirecikli, Uzay, 2019).

Covid-19 sürecinde yaşanılan olağanüstü durumun bir sonucu olarak işletmelerin finansal tablolarında da alışılmışın dışında bazı tutar ya da açıklamalara rastlamak mümkündür. Finansal tablolarda karşılaşılan bu tutar ya da açıklamalar denetçiyi, önemlilik seviyesini belirlerken genel kabul görmüş kural ve uygulamaların dışına çıkıp çıkmayacağına karar vermesi konusunda yönlendirebilmektedir. Aynı zamanda denetçinin, içinde bulunulan durumdan etkilenmesi muhtemel hesaplara ayrı bir önemlilik seviyesi belirleyip belirlemeyeceğini gözden geçirmesi yararlı olabilir ("Covid-19 Salgınının”, 2020).

\subsubsection{Denetim Kanttlarn}

Denetçinin temel amaçlarından biri denetim raporunda belirteceği görüşüne yeterli dayanağı oluşturacak denetim kanıtlarını elde etmektir. İçinde bulunduğumuz sürecin yarattığı olağanüstü koşullar nedeniyle uygulanan kısıtlamalar denetçinin bu kanıtlara ulaşmasını zorlaştırmaktadır. Bu şartlar altında denetçiler, denetim kanıtlarını toplamak için alternatif yollar aramak zorunda kalabilir. Bu alternatiflerin daha çok teknoloji tabanlı prosedürler olacağını söylemek mümkündür.

Örneğin; denetçi, düzenlemesi gereken toplantıları sanal ortamda düzenleyebilir veya uygulaması gereken dış teyit prosedürlerini yine sanal ortam üzerinden yürütebilir. Denetçinin bu tür prosedürleri uygularken, bunların fiziki prosedürlere göre güvenilirliğinin ve kalitesinin daha düşük olabileceği riskini de değerlendirmesi ve bu değerlendirmesine raporunda yer vermesi gerekir. Denetçinin, raporunda Covid-19 salgınından kaynaklı kısıtlamalardan dolayı uygulayamadığı önemli denetim prosedürlerinin görüşü üzerindeki etkisinden bahsetmesi gerekebilir ("Covid-19 Salgınının”, 2020; TÜRMOB, 2020).

\subsection{5. İşletmenin Sürekliliği}

Finansal tablolar, işletmelerin ömrünün sınırsız olduğu ve öngörülebilir gelecekte faaliyetlerine devam edeceği anlamına gelen "işletmenin sürekliliği" temel varsayımıyla hazırlanmaktadır. Bu temel varsayım ve bu varsayımın denetçi raporuna etkisiyle ilgili, denetim sürecinde denetçinin sorumlulukları BDS 570 "İşletmenin Sürekliliğ̈i" standardında düzenlenmiştir.

Bu standart gereği, denetçinin;

$>$ Zorunlu risk değerlendirme prosedürlerini uygularken, işletmenin sürekliliğini olumsuz etkilemeye yönelik ciddi şüphe oluşturabilecek olaylarla ilgili önemli bir belirsizliğin olup olmadığını değerlendirmek,

> Bu süreçte, işletmenin sürekliliğiyle ilgili yönetimin ön değerlendirmesinin olup olmadığını kontrol etmek ve bir ön değerlendirme mevcut ise, ön değerlendirmeyi yönetimle beraber değerlendirip bu 


\section{B. A. Adana - M. Özbirecikli 12/2 (2020) 2080-2093}

sürecin sonunda ciddi şüphe oluşturabilecek olaylara rastlarsa, yönetimin bu olaylara karşı planlarının mevcut olup olmadığını değerlendirmek,

> Denetim sürecinde, işletmenin sürekliliğiyle ilgili denetim kanıtlarına şüpheyle yaklaşmak,

$>$ Denetim sonunda ulaştı̆̆ı tüm bilgilerin, yönetimin değerlendirmesinde yer alıp almadığını irdelemek,

> Yönetim, işletmenin sürekliliğiyle ilgili bir değerlendirmede bulunmamışsa; yönetimden değerlendirme yapmasını istemek

gibi sorumlulukları vardır (BDS 570, 2017).

Covid-19 sürecinde yaşanan ticaret kısıtlamaları, nakit akış sıkıntıları gibi durumlar işletmelerin sürekliliğini bu sürecin kilit noktası haline getirmiştir. Bu sürecin yarattı̆̆ belirsizlik ortamı işletmelerin sürekliliğiyle ilgili tahmin yapmayı son derece zorlaştırmıştır. Bu süreçte denetçi, işletmenin sürekliliğiyle ilgili değerlendirmede bulunurken; eğer yönetim işletmenin sürekliliğiyle ilgili bir değerlendirmede bulunmamışsa, değerlendirme talep etme ya da yönetimin değerlendirmesini değişen koşullara bağlı olarak güncellemesini isteme gibi ek denetim prosedürlerine başvurabilir. Ek olarak işletme yönetiminden dipnotların genişletilmesini talep edebilir ("Covid-19 Salgınının", 2020; TÜRMOB, 2020).

Denetçi, muhasebe tahminleri ve ilgili açılamalara yönelik sorumluluklarının düzenlendiği ve tahminlerle ilgili yanlışlıkların değerlendirilmesi için açıklamaların yer aldığı BDS 540'a göre, muhasebe tahminlerinin yeniden gözden geçirilmesini isteyebilir.

BDS 540 “Muhasebe Tahminlerinin ve İlgili Açıklamaların Bağımsız Denetimi” standardı gereği, denetçinin;

> Muhasebe tahminleri ve tahminlere yönelik açılamaların, uygulanan finansal raporlama çerçevesince uygun olup olmadığını veya herhangi bir yanlışlık içerip içermediğini, elde ettiği denetim kanıtları ve uyguladığı denetim prosedürlerine istinaden değerlendirmek,

> Muhasebe tahminleriyle ilgili yönetimin belirttiği önemli yanlışlık risklerini irdelerken, kontrol riskine yönelik ayrı bir değerlendirme yapmak,

$>$ Muhasebe tahminlerinin, karmaşık, sübjektif veya diğer yapısal risk faktörlerinden etkilenmiş olma ihtimaline karşın mesleki şüpheciliği elden bırakmamak,

> Geçmişteki muhasebe tahminlerinin sonuçlarını, cari dönemdeki önemli yanlışlık risklerini belirleme ve değerlendirme süreçlerinde yol göstermesi açısından değerlendirmek,

> Muhasebe tahminlerine ilişkin, önemli yanlışlık risklerini belirleyip değerlendirmek, bu risklere yönelik denetim prosedürlerini oluşturmak ve uygulamak,

gibi sorumlulukları bulunmaktadır (BDS 540, 2019).

Bu öngörülemeyen ortamda işletmelerin mevcut kaynaklarıyla ne kadar ayakta durabileceğini kestirmek çok zor olmakla beraber sürecin uzamasıyla birlikte kısıtlamaların da uzayacağı düşünüldügünde denetçinin, işletmelerin nakit sıkıntısı çekme ihtimalini ve yeni kaynak yaratmanın zorluklarını göz önünde bulundurarak değerlendirmelerini yapması gerekecektir (“Covid-19 Salgınının”, 2020; TÜRMOB, 2020).

Denetçinin BDS 540 açısından üzerinde durması gereken en önemli tahmin konularından biri şüpheli alacak karşılığı konusudur. Özellikle talep düşüklüğünün yaşandığı ve/veya yaşanacağı sektörlerde nakit yaratma potansiyeli azalan işletmelerde borç ödeme gücü de düşecektir. Borçların ödenmesi için alternatif yollar bulamayan işletmelerin şüpheli alacak hesaplarının oluşmasına neden olabileceği açıktır. Dolayısıyla bu duruma maruz kalabilecek sektörlerde faaliyet gösteren işletmelerin şüpheli alacak tahminlerini gözden geçirmeleri gerekecektir.

\subsubsection{Grup Denetimleri}

“Topluluk Sorumlu Denetçisi" sıfatıyla topluluk finansal raporlarını denetleyen denetçi, topluluk denetiminin mevzuata uygunluğu gibi hususları değerlendirirken aynı zamanda hazırlanan raporun, mevcut koşullara uygunluğundan da sorumludur. Yaşanan Covid-19 sürecinin kısıtlamalarından dolayı denetçi, tüm birimlerden yeterli düzeyde güvenilir kanıt elde edemeyebilir.

Örneğin bağlı birimlerin denetçilerinin çalışmalarını denetleme imkanı bulamayabilir. Bu gibi durumlarda denetçi alternatif denetim tekniklerine yönelerek daha fazla güvenilir kanıt elde etmeye çalışabilir. Denetçi, 
uyguladığı bu alternatif tekniklere ve bu teknikler sonucunda elde ettiği bilgilerin görüşüne olan etkisine raporunda yer verir (“Covid-19 Salgınının”, 2020; TÜRMOB, 2020).

\subsubsection{Kilit Denetim Konularn}

Bilgi kullanıcılarının; finansal tabloları ve denetim sürecinde en fazla öneme sahip konuları anlamasına yardımcı olmak aynı zamanda denetim sürecinin şeffaflığını artırmak amacıyla denetim raporunda yer verilen kilit denetim konularına ilişkin denetçinin sorumlulukları, BDS 701 "Kilit Denetim Konularının Bağımsız Denetçi Raporunda Bildirilmesi" standardında düzenlenmiştir. Bu standart gereği, denetçinin;

$>$ Önemli yanlışlık riskinin daha fazla olduğunu düşündüğü konular ya da yüksek tahmin belirsizliğine sahip muhasebe tahminleri gibi önemli hususlara öncelik vermek,

$>$ Kilit denetim konularını, mesleki muhakemesine göre belirlediğini ve bu konuların sadece cari döneme ait olduğunu bildirmek,

$>$ Konuların bir bütün olarak denetim sürecinde ve görüş oluşturulurken göz önüne alındığını, bu konulara yönelik ayrı bir görüş vermediğini bildirmek,

$>$ Belirlenen konunun, kilit denetim konusu olarak belirlenmesinin sebebini ve nasıl ele alındığını açiklamak,

gibi sorumlulukları bulunmaktadır (BDS 701, 2019).

Kilit denetim konuları, bağımsız denetim sürecinin en önemli konuları olarak bilinir. Denetçi içinde bulunduğumuz olağanüstü durumu kilit denetim konusu olarak ele alabileceği gibi, kilit denetim konularını belirlerken finansal raporlarda Covid-19'dan önemli düzeyde etkilenmesi muhtemel hesap kalemlerini değerlendirebilir ("Covid-19 Salgınının", 2020).

Kilit denetim konuları denetlenen işletme ile ilgili olarak denetçinin raporlanmasını gerekli gördüğü konular olmalıdır. Örneğin;

> Ciddi riskli görülen veya önemli yanlışlık riskinin yüksek olduğu alanlar (Stoklar, İlişkili taraf işlemleri vbg)

> Önemli yargı içeren alanlar (şüpheli alacak tahminleri, MDV faydalı ömür tahminleri vbg)

> Denetim sırasında karşılaşılan önemli zorluklara ilişkin hususlar (Depo sayısının fazla ve karmaşık olması, depo sayımına katılmanın mümkün olmaması)

> Önemli işlem ve olayların etkisi (ilişkili taraflarla önemli işlemler veya salgın, doğal afet, ekonomik kriz gibi olağandışı durumların etkileri, önemli bir şirket satın alma işlemi ile konsolide tabloların değerinin çok değişmesi)

> Denetçinin planlanan yaklaşımında önemli değişikliklere neden olan konular (iç kontrol sisteminde saptanan zayıflık ve zafiyetler, şirketin üst yöneticilerinin değişmesi, yılsonuna doğru yeni bir fabrika almış olması gibi)

Dolayısıyla kilit denetim konuları Covid-19 salgını etkisi açısından değerlendirildiğinde denetlenen işletme ile ilgili olarak denetçinin raporlanmasını gerekli gördüğü konulara BDS'lerin uygulama boyutu dikkate alınarak şu örnekler verilebilir:

> Salgından dolayı depo sayımına katılmanın mümkün olmaması nedeniyle denetçi denetimi gerçekleştirmek açısından önemli bir kısıtlamayla karşı karşıya kalacaktır. Bu durumda sınırlı olumlu görüş vermesi gerekebilir.

$>$ Salgın gibi önemli bir olayın etkisi dikkate alındığında denetçinin planlanan yaklaşımında önemli değişiklikler yapması gerekebilir. Denetim sürecinin başında belirlenen önemlilik düzeyi ve risk seviyesi ile salgın sürecinde belirlenecek önemlilik düzeyi ve risk seviyesi farklı olabilir. Bu denetim yaklaşımı değişikliği denetçinin görüşünü de etkileyebilir.

\subsubsection{Denetçi Raporundaki Potansiyel Etkiler}

Covid-19 salgını işletmelerin denetim süreçlerini etkileyeceği gibi yukarıda açıklanan sebeplerle bu sürecin çıkısı olan raporu da etkileyecektir. Örneğin; denetçi, salgının işletmeye olan etkilerini vurgulamak için BDS 
706'da düzenlenen; bilgi kullanıcılarının kararlarını etkileyecek düzeyde öneme sahip, finansal tablolarda dikkat çekilmesi gereken konuların veya finansal tablolarda yer almayan ama denetim süreci, denetçinin sorumlulukları ve raporun anlaşılmasıyla ilgili olan konuların işaret edildiği "Dikkat Çekilen Hususlar ve Diğer Hususlar" paragrafları ya da işletmenin sürekliliğiyle ilgili bilinmezliğin olması durumunda "İşletmenin Sürekliliğiyle İlgili Önemli Belirsizlik" paragrafı ekleyebilir (BDS 706, 2017).

Ayrıca Covid-19'un kilit denetim konularından biri olarak belirlenmesi veya denetçinin yeterli ve uygun denetim kanıtı elde etmede Covid-19 kısıtlamalarından dolayı yaşayabileceği zorlukların sonucunda Covid19 sürecinin etkilerine dair değerlendirmelerin yetersiz kalmasıyla birlikte denetimi sinırlandırması söz konusu olabilir (“Covid-19 Salgınının", 2020; TÜRMOB, 2020).

\subsubsection{Denetçi Görüşünün Oluşturulması}

Covid-19 süreci açısından oluşabilecek bir diğer etki de bağımsız denetçinin raporunda olumlu görüş dışında bir görüş vermesi gerektiği sonucuna varmasıdır. Denetçinin bu mevcut duruma uygun görüş ve rapor oluşturma sorumluluğu ve olumlu görüş dışında bir görüş verildiği durumlarda raporun şekil ve içerik bakımından nasıl etkilendiği BDS 705 "Bağımsız Denetçi Raporunda Olumlu Görüş Dışında Bir Görüş Verilmesi" standardında ele alınmıştır (BDS 705, 2017). Dolayısıyla denetçi, Covid-19 sürecinin işletme ve denetim süreci üzerindeki etkilerini belirli kıstaslara göre değerlendirerek denetçi görüşünü şekillendirebilir. Nitekim

> İşletmenin Sürekliliği varsayımını kullanmak uygunsa

> Önemli bir belirsizliğin olması durumunda; işletmenin sürekliliği varsayımını kullanmak uygunsa ve finansal tablo dipnotlarında yeterli açıklama yapılmışsa. (Ancak burada «İşletmenin Sürekliliği ile ilgili Önemli Belirsizlik» başlığı altında ilgili belirsizlik açıklanmalıdır)

> Yeterli ve uygun denetim kanıtı elde etmiş olan denetçi, yanlışlıkların tek başına veya toplu olarak önemli olmadığı ve finansal tablolar üzerindeki etkilerinin yaygın olmadığı sonucuna varırsa

Olumlu görüş bildirebilir.

> Yeterli ve uygun denetim kanıtı elde etmiş olan denetçi, yanlışlıkların tek başına veya toplu olarak finansal tablolar için önemli ve (etkisinin) yaygın olduğu sonucuna varırsa

> İşletmenin Sürekliliği varsayımını kullanmak uygun olmamakla birlikte, şirket yönetimi süreklilik konusunda bir sorun yokmuş gibi davranıyor ve açıklama yapmıyorsa

> Önemli bir belirsizliğin olması durumunda; işletmenin sürekliliği varsayımını kullanmak uygunsa ancak finansal tablo dipnotlarında yeterli açılama yapılmamışsa ve belirsizliğin finansal tablolar üzerindeki etkileri yaygin ise

Olumsuz görüş bildirebilir.

> Yeterli ve uygun denetim kanıtı elde etmiş olan denetçi, yanlışlıkların tek başına veya toplu olarak önemli olduğu ancak etkisinin yaygın olmadığı_sonucuna varırsa (örneğin stoklar için yaygın olmayan önemli yanlışlık tespiti varsa)

> Görüşüne dayanak teşkil edecek yeterli ve uygun denetim kanıtı elde edememekle birlikte denetçi, varsa- tespit edilmemiş yanlışlıkların finansal tablolar üzerindeki muhtemel etkilerinin önemli olabileceği ancak yaygın olmayabileceği sonucuna varırsa (örneğin stokların sayımını sağlıklı gözlemleyememiştir ve varolma ve değerleme iddialar için şüpheleri vardır)

> Önemli bir belirsizliğin olması durumunda; işletmenin sürekliliği varsayımını kullanmak uygunsa ancak finansal tablo dipnotlarında yeterli açılama yapılmamışsa ve belirsizliğin finansal tablolar üzerindeki etkileri yaygın değilse (Örneğin, mahkeme sürecinde olan çok sayıda işçi tazminat davası vardır ve tazminat tutarları önemlidir, ancak etkisi yaygın değildir ve bu husus açıklanmamıştır. Ayrıca süresi yenilenmemiş patent sözleşmelerinden kaynaklı ihlallerden dolayı henüz mahkemeye intikal etmemiş ancak mahkemelik olması kuvvetle muhtemel hak talepleri olabilir)

Sınırlı (şartlı) görüş bildirebilir. 
> Denetçi, görüşüne dayanak teşkil edecek yeterli ve uygun denetim kanıtı elde edemezse ve -varsa- tespit edilmemiş yanlışlıkların finansal tablolar üzerindeki muhtemel etkilerinin önemli ve yaygın olabileceği sonucuna varırsa,

> Denetçi, birden fazla belirsizlik içeren istisnai durumlarda, belirsizliklerin her birine ilişkin yeterli ve uygun denetim kanıtı elde edilmiş olmasına bağlı kalmaksızın, belirsizliklerin muhtemel etkileşimi ve finansal tablolar üzerindeki olası etkileri sebebiyle finansal tablolara ilişkin görüş oluşturmanın mümkün olmadığı sonucuna varırsa

Görüş vermekten kaçınır.

Dolayısıyla salgın gibi önemli bir olayın işletmenin sürekliliği ile ilgili önemli bir belirsizliğe neden olması, işletmenin sürekliliği varsayımını kullanmanın uygunluğunu etkilemesi, yeterli kanıt elde edilmesini etkilemesi gibi durumlar dikkate alındığında denetçinin görüşünü şekillendirmesinde etkili olması doğaldır.

\subsubsection{Bilanço Tarihinden Sonraki Olaylar}

Finansal tablolar, bilanço tarihinden sonraki olaylardan etkilenebilir. Bilanço tarihinden sonra gerçekleşen ve finansal tablolarda düzeltme yapılmasını gerektiren olaylarla ilgili olarak denetim sürecinde denetçinin sorumlulukları BDS 560 “Bilanço Tarihinden Sonraki Olaylar" standardında düzenlenmiştir (BDS 560, 2017).

Covid-19'un 2019 sonlarında 2020 başından itibaren Çin Halk Cumhuriyeti dışında görüldüğü ve DSÖ tarafından 11 Mart 2020 tarihinde salgın olarak ilan edildiği göz önünde bulundurulduğunda, salgının etkilerinin finansal tabloların tarihi ile denetçi raporu tarihi arasında görüldüğünü söylemek mümkündür. Bu durumun bilanço tarihinden sonraki bir olay olarak değerlendirilip finansal tablolarda yer alması gerekir. Ayrıca denetçiler, bu süreçte salgının işletmeler üzerindeki etkilerini, bu etkilere görüşünde yer verip vermeyeceğini ve yapılan açılamaların yeterli olup olmadığını değerlendirmelidir ("Covid-19 Salgınının", 2020; TÜRMOB, 2020).

\subsection{Covid-19 İle İlgili Açılama İçeren Denetçi Raporu Örnekleri}

Bu başlık altında Covid-19 ile ilgili açıklama içeren denetçi raporu örneklerine yer verilmektedir. Aşağıda yer alan örnekler bağımsız denetime tabi şirketlerin www.kap.org.tr ve www.spk.gov.tr internet sitelerinde yayımlanan raporlardan alınmıştır. Çalışmanın yapıldığı tarih (04.06.2020) itibariyle yayımlanmış olan denetçi raporu sayısı 81 adet olup bunlardan Covid-19 etkilerini içeren örnekler seçilmiştir.

Tablo 1. Covid-19 İle İlgili Açılama İçeren Denetçi Raporu Örnekleri

\begin{tabular}{|c|c|c|c|}
\hline \multicolumn{3}{|c|}{$\begin{array}{l}\text { Firma: Kervansaray Yatırım Holding } \\
\text { A.Ş. }\end{array}$} & $\begin{array}{l}\text { Bağımsız Denetçi: Yeditepe Bağımsız Denetim ve YMM } \\
\text { A.Ş. }\end{array}$ \\
\hline \multicolumn{2}{|c|}{$\begin{array}{l}\text { Bağımsız Denetim } \\
\text { Görüşüi }\end{array}$} & \multicolumn{2}{|c|}{ Görüş Vermekten Kaçınma } \\
\hline \multicolumn{2}{|c|}{$\begin{array}{l}\text { Covid-19 ile İlgili } \\
\text { Bilginin Geçtiği Bölüm }\end{array}$} & \multicolumn{2}{|c|}{ Görüş Vermekten Kaçınmanın Dayanağ } \\
\hline $\begin{array}{l}\text { Covid-19 ile } \\
\text { İlgili } \\
\text { Açıklama }\end{array}$ & \multicolumn{3}{|c|}{$\begin{array}{l}\text { Tüm dünyada olduğu gibi ülkemizde de Covid-19 salgınının önlenmesi için } \\
\text { kısıtlayıcı tedbirler getirilmiştir. Bu kapsamda T.C. İçişleri Bakanlığı tarafından farklı } \\
\text { tarihlerde sokağa çıkma yasakları, } 30 \text { büyükşehiri kapsayan şehir giriş/çış } \\
\text { kısıtlamaları nedeniyle, Bağımsı Denetim Standartları (BDS) } 315 \text { "İşletme ve } \\
\text { Çevresini Tanımak Suretiyle "Önemli Yanlışlık" Risklerin Belirlenmesi ve } \\
\text { Değerlendirmesi" standardı uyarınca, İstanbul dışında bulunan Grup otellerinin iç } \\
\text { kontrol çevresi, süreçleri ve etkinliklerine ilişkin denetimler gerçekleştirilememiştir. } \\
\text { Yine aynı nedenlerden BDS 560'ın 6'ncı paragrafında yer verilen "Denetçi, finansal } \\
\text { tabloların tarihi ile denetçi raporu tarihi arasında gerçekleşen ve finansal tablolarda } \\
\text { düzeltme veya açıklama yapılmasını gerektiren tüm olayların belirlendiğine dair } \\
\text { yeterli ve uygun denetim kanıtı elde etmek için tasarlanan denetim prosedürlerini }\end{array}$} \\
\hline
\end{tabular}




\begin{tabular}{|l|l|l|}
\hline \multicolumn{2}{|l|}{} & \multicolumn{2}{l}{$\begin{array}{l}\text { uygular" hükmü uygulanamamıştır. Ayrıca maddi duran varlıklara ilişkin fiziki } \\
\text { kontrol ve değer düşüklüğ̈̈ testleri yapılamamıştır }\end{array}$} \\
\hline $\begin{array}{l}\text { Covid-19 ile İlgili } \\
\text { Bilginin Geçtiği Bölüm }\end{array}$ & Diğer hususlar \\
\hline $\begin{array}{l}\text { Covid-19 ile } \\
\text { İlgili } \\
\text { Açıklama }\end{array}$ & $\begin{array}{l}\text { Çin Halk Cumhuriyet'inin Wuhan kentinde 2019 yılının Aralık ayında ortaya çıkan } \\
\text { Koronavirüs (Covid-19) salgını tüm dünyaya yayılmış ve 11 Mart 2020 tarihinde } \\
\text { Dünya Sağlı Örgütü tarafından Pandemi ilan edilmiştir. Ülkemizde ve tüm dünyada } \\
\text { Covid-19 salgınına ilişkin alınan önlemler kapsamında üretim, ticaret ve ulaşım gibi } \\
\text { birçok alanda kısıtlayıcı tedbirler getirilmiştir. Getirilen bu tedbirlerin ve yavaşlayan } \\
\text { ekonomik aktivitelerin etkisiyle, şirketlerin gelirlerinin düşmesi ve nakit akışlarının } \\
\text { olumsuz etkilemesi muhtemeldir. }\end{array}$ \\
\hline $\begin{array}{l}\text { Covid-19 ile İlgili } \\
\text { Bilginin Geçtiği Bölüm }\end{array}$ & $\begin{array}{l}\text { Not.32 Bilanço Tarihinden Sonraki Olaylar } \\
\text { Covid-19 ile } \\
\text { İlgili } \\
\text { Açılama }\end{array}$ & $\begin{array}{l}\text { Çin Halk Cumhuriyet'inin Wuhan kentinde 2019 yllının Aralık ayında ortaya çıan } \\
\text { Koronavirüs (Covid-19) salgını tüm dünyaya yayılmıs ve 11 Mart 2020 tarihinde } \\
\text { Dünya Sağlik Örgütü tarafından Pandemi ilan edilmiştir. Ülkemizde ve tüm dünyada } \\
\text { Koronavirüs (Covid-19) salgınına ilişkin alınan önlemler kapsamında üretim, ticaret } \\
\text { ve ulaşım gibi birçok alanda kısıtlayıcı tedbirler getirilmiştir. Getirilen bu tedbirlerin } \\
\text { ve yavaşlayan ekonomik aktivitelerin etkisiyle, şirketlerin gelirlerinin düşmesi ve } \\
\text { nakit akışlarının olumsuz etkilemesi muhtemeldir. }\end{array}$ \\
\hline
\end{tabular}

\begin{tabular}{|c|c|c|c|}
\hline \multicolumn{3}{|c|}{$\begin{array}{l}\text { Firma: Eryap Mühendislik İnşaat } \\
\text { Taahhüt Turizm Sanayi ve Ticaret A.Ş. }\end{array}$} & $\begin{array}{l}\text { Bağımsız Denetçi: Mercek Bağımsız Denetim ve YMM } \\
\text { A.Ş. }\end{array}$ \\
\hline \multicolumn{2}{|c|}{$\begin{array}{l}\text { Bağımsız Denetim } \\
\text { Görüişü }\end{array}$} & \multicolumn{2}{|c|}{ Sınırlı Olumlu Görüş } \\
\hline \multicolumn{2}{|c|}{$\begin{array}{l}\text { Covid-19 ile İlgili } \\
\text { Bilginin Geçtiği Bölüm }\end{array}$} & \multicolumn{2}{|c|}{ İşletmenin Sürekliliğinin Değerlendirilmesi } \\
\hline $\begin{array}{l}\text { Covid-19 ile } \\
\text { İlgili } \\
\text { Açıklama }\end{array}$ & \multicolumn{3}{|c|}{$\begin{array}{l}\text { Tüm dünyada olduğu gibi ülkemizde de yaşanan Koronavirüs salgını nedeniyle } \\
\text { ortaya çıkan durum ve gelişmeler Şirket'in sürekliliğini devam ettirme kabiliyetine } \\
\text { ilişkin şüphe oluşturabilecek önemli bir belirsizliğin mevcut olduğunu göstermekle } \\
\text { birlikte, Şirket yönetimi öngörülebilir gelecekte olağan faaliyetlerine devam } \\
\text { edeceğini açıklamıştır. Bu husus, tarafımızca verilen görüşü etkilememektedir. }\end{array}$} \\
\hline \multicolumn{2}{|c|}{$\begin{array}{l}\text { Covid-19 ile İlgili } \\
\text { Bilginin Geçtiği Bölüm }\end{array}$} & \multicolumn{2}{|c|}{ Dikkat Çekilen Hususlar } \\
\hline $\begin{array}{l}\text { Covid-19 ile } \\
\text { İlgili } \\
\text { Açıklama }\end{array}$ & \multicolumn{3}{|c|}{$\begin{array}{l}\text { Şirket'in bilanço tarihinden sonraki olayların açıklandığı, finansal tabloların } 33 \text { nolu } \\
\text { dipnotuna dikkat çekeriz. Dünya Sağlık Örgütünün, } 2020 \text { yılının Ocak ayından } \\
\text { itibaren yapmış olduğu açılamalar ve } 11 \text { Mart } 2020 \text { tarihinde ilan etmiş olduğu } \\
\text { pandemi çerçevesinde, dünyada ve ülkemizde yayılan yeni tip Koronavirüsü (Covid- } \\
\text { 19) salgınına karşı alınan önlemlerden dolayı Şirketin faaliyetlerinde yaşanması } \\
\text { muhtemel aksaklıklar dolayısıyla satış gelirleri ile tahsilâtlardaki düşüşün etkisiyle } \\
\text { finansal durumu ve faaliyet sonuçları olumsuz yönde etkilenmesi olasıdır. Kamu } \\
\text { otoriteleri tarafından vergi, sosyal güvenlik gibi ödemelere ilişkin alınan erteleme } \\
\text { kararları, koruyucu tedbirler ve destekleyici uygulamalar ile bu sürecin olumsuz }\end{array}$} \\
\hline
\end{tabular}




\begin{tabular}{|c|c|c|}
\hline & \multicolumn{2}{|c|}{$\begin{array}{l}\text { etkileri giderilmeye çalışılmaktadır. Bu salgının ekonomik etkilerinin hesap dönemi } \\
\text { sonu itibariyle belirsiz olması nedeniyle, Şirket'in } 31 \text { Aralık } 2019 \text { tarihli finansal } \\
\text { tabloları üzerindeki etkileri tahmin edilememektedir. Ancak bu husus, tarafımızca } \\
\text { verilen görüşü etkilememektedir. }\end{array}$} \\
\hline \multicolumn{2}{|r|}{$\begin{array}{l}\text { ili } \\
\text { i Bölüm }\end{array}$} & Dipnotlar-33: Raporlama Döneminden Sonraki Olaylar \\
\hline $\begin{array}{l}\text { Covid-19 ile } \\
\text { İlgili } \\
\text { Açıklama }\end{array}$ & \multicolumn{2}{|c|}{$\begin{array}{l}\text { Dünya Sağlık Örgütünün, } 2020 \text { yılının Ocak ayından itibaren yapmış olduğu } \\
\text { açılamalar ve } 11 \text { Mart } 2020 \text { tarihinde ilan etmiş olduğu pandemi çerçevesinde, } \\
\text { dünyada ve ülkemizde yayılan yeni tip Koronavirüsü (Covid-19) salgınına karşı } \\
\text { alınan önlemlerden dolayı Şirketin faaliyetlerinde yaşanması muhtemel aksaklıklar } \\
\text { dolayısıyla satış gelirleri ile tahsilatlardaki düşüşün etkisiyle finansal durumu ve } \\
\text { faaliyet sonuçları olumsuz yönde etkilenmesi olasıdır. Kamu otoriteleri tarafından } \\
\text { vergi, sosyal güvenlik gibi ödemelere ilişkin alınan erteleme kararları, koruyucu } \\
\text { tedbirler ve destekleyici uygulamalar ile bu sürecin olumsuz etkileri giderilmeye } \\
\text { çalışılmaktadır. Bu salgının ekonomik etkilerinin hesap dönemi sonu itibariyle } \\
\text { belirsiz olması nedeniyle, Şirket'in } 31.12 .2019 \text { tarihli finansal tabloları üzerindeki } \\
\text { etkileri tahmin edilememektedir. }\end{array}$} \\
\hline \multicolumn{2}{|c|}{$\begin{array}{l}\text { Covid-19 ile İlgili } \\
\text { Bilginin Geçtiği Bölüm }\end{array}$} & Kilit Denetim Konuları \\
\hline $\begin{array}{l}\text { Covid-19 ile } \\
\text { İlgili } \\
\text { Açılama }\end{array}$ & \multicolumn{2}{|c|}{$\begin{array}{l}31 \text { Aralık } 2019 \text { tarihi itibarıyla } 299.363 .174 \text { TL tutarındaki toplam ticari alacaklar } \\
\text { finansal tabloların önemli bir bölümünü oluşturmaktadır. Ticari alacaklar için şüpheli } \\
\text { alacak karşılığının belirlenmesinde borçlunun ödeme yeteneği, önceki dönemlerde } \\
\text { tahsil edilemeyen alacaklarına ilişkin veriler, içinde bulunulan sektörde ve cari } \\
\text { ekonomik ortamda ortaya çıkan olağanüstü koşullar, müşterilerden alınan } \\
\text { teminatlar, müşterilerin ödeme performansları, alacakların vade analizleri gibi } \\
\text { unsurlar dikkate alınmakta ve bu çalışmalara göre yapılan tahminler } \\
\text { muhasebeleştirilmektedir. Bu kapsamda, ticari alacaklara ilişkin ayrılan değer } \\
\text { düşüklüğü karlığının tutarını belirlenmesi önemli düzeyde yönetimin } \\
\text { muhakemesini ve varsayımlarını içerdiğinden bu konu kilit denetim konularından } \\
\text { biri olarak belirlenmiştir. }\end{array}$} \\
\hline
\end{tabular}

\begin{tabular}{|c|c|c|c|}
\hline \multicolumn{3}{|c|}{$\begin{array}{l}\text { Firma: İş Gayrimenkul Yatırım } \\
\text { Ortaklığı }\end{array}$} & $\begin{array}{l}\text { Bağımsız Denetçi: Güney Bağımsız Denetim ve SMMM } \\
\text { A.Ş. }\end{array}$ \\
\hline \multicolumn{2}{|c|}{$\begin{array}{l}\text { Bağımsız Denetim } \\
\text { Görüşüu }\end{array}$} & \multicolumn{2}{|c|}{3 Aylık Ara Hesap Dönemine Ait Finansal Tabloların Denetimi } \\
\hline \multicolumn{2}{|c|}{$\begin{array}{l}\text { Covid-19 ile İlgili } \\
\text { Bilginin Geçtiği Bölüm }\end{array}$} & \multicolumn{2}{|c|}{ Dikkat Çekilen Hususlar } \\
\hline $\begin{array}{l}\text { Covid-19 ile } \\
\text { Ilgili } \\
\text { Açıklama }\end{array}$ & \multicolumn{3}{|c|}{$\begin{array}{l}\text { Koronavirüs salgını sebebiyle etkilenen faaliyetler ile ilgili olarak Şirketin } \\
\text { açıklamalarının olduğu } 26^{\prime} \text { 'no'lu dipnota dikkat çekeriz. Bu husus tarafımızca verilen } \\
\text { sonucu etkilememektedir }\end{array}$} \\
\hline
\end{tabular}




\begin{tabular}{|c|c|c|c|}
\hline \multicolumn{3}{|c|}{ Firma: Soma Termik Sant. Elek. Üret. A.Ş. } & $\begin{array}{l}\text { Bağımsız Denetçi: KPMG Bağımsız Denetim ve SMMM } \\
\text { A.Ş. }\end{array}$ \\
\hline \multicolumn{2}{|c|}{$\begin{array}{l}\text { Bağımsız Denetim } \\
\text { Görüşüu }\end{array}$} & \multicolumn{2}{|c|}{ Sınırlı Olumlu Görüş } \\
\hline \multicolumn{2}{|c|}{$\begin{array}{l}\text { Covid-19 ile İlgili } \\
\text { Bilginin Geçtiği Bölüm }\end{array}$} & \multicolumn{2}{|c|}{ İşletmenin Sürekliliğiyle İlgili Önemli Belirsizlik } \\
\hline $\begin{array}{l}\text { Covid-19 ile } \\
\text { İlgili } \\
\text { Açılama }\end{array}$ & \multicolumn{3}{|c|}{$\begin{array}{l}\text { Covid-19 salgınının ve yaşanan döviz kurundaki artışların işletmenin sürekliliğine } \\
\text { etkileri, bu dipnotlarda açıklanan olay veya şartlar ve diğer hususlarla birlikte } \\
\text { değerlendirildiğinde şirketin sürekliliğini devam ettirme kabiliyetine ilişkin ciddi } \\
\text { şüphe oluşturabilecek önemli belirsizliklerin mevcut olduğunu göstermektedir. }\end{array}$} \\
\hline
\end{tabular}

\begin{tabular}{|c|c|c|c|}
\hline \multicolumn{3}{|c|}{ Firma: Martı Gayrimenkul Yat. Ort. A.Ş. } & Bağımsız Denetçi: Güreli YMM ve Bağımsız Denetim A.Ş. \\
\hline \multicolumn{2}{|c|}{$\begin{array}{l}\text { Bağımsız Denetim } \\
\text { Görüşüu }\end{array}$} & \multicolumn{2}{|c|}{ Sınırlı Olumlu Görüş } \\
\hline \multicolumn{2}{|c|}{$\begin{array}{l}\text { Covid-19 ile İlgili } \\
\text { Bilginin Geçtiği Bölüm }\end{array}$} & \multicolumn{2}{|c|}{ Sınırlı Olumlu Görüşün Dayanağı } \\
\hline $\begin{array}{l}\text { Covid-19 ile } \\
\text { İlgili } \\
\text { Açıklama }\end{array}$ & \multicolumn{3}{|c|}{$\begin{array}{l}\text { Şirketin 31.10.2019, } 18.12 .2019 \text { ve } 10.01 .2020 \text { tarihinde Kamuyu Aydınlatma } \\
\text { Platformunda açıladığ üzere, Denizbank A.Ş. Ve Deniz Faktoring A.Ş.'den } \\
\text { kullanılmış olan ve factoring kuruluşu tarafından icra takibine konu edilmiş ve } \\
\text { tamamına muacceliyet kazandırılmıştır. Denetim faaliyetleri esnasında Banka'ya } \\
\text { mutabakat yazısı gönderilmiş olup; banka tarafından cevap yazısında gönderilen } \\
\text { kredi bilgilerine yer verilemeyeceği ve icra dairelerinden kapak hesaplarının } \\
\text { alınabileceğine dair açılama yapılmıştır. COVID-19 salgınından dolayı icra } \\
\text { dairelerinin kapalı olması nedeniyle icra dairesinden } 31.03 .2020 \text { tarihi itibariyle icra } \\
\text { kapak hesapları temin edilememiştir. Kredilere ilişkin faiz tahakkukları şirket } \\
\text { yönetimi tarafından önceki dönemlerde ( } 31.12 .2019 \text { itibariyle) temin edilen icra kapak } \\
\text { yazılarındaki faiz oranları bazalınarak hesaplanmıştır. Denetim şirketimiz tarafından } \\
\text { mevcut fiili durumu gösterir sağlıklı bir mutabakat yapabilme imkânı } \\
\text { bulunamamıştır. }\end{array}$} \\
\hline \multicolumn{2}{|c|}{$\begin{array}{l}\text { Covid-19 ile İlgili } \\
\text { Bilginin Geçtiği Bölüm }\end{array}$} & \multicolumn{2}{|c|}{ Dikkat Çekilen Hususlar } \\
\hline $\begin{array}{l}\text { Covid-19 ile } \\
\text { İlgili } \\
\text { Açıklama }\end{array}$ & \multicolumn{3}{|c|}{$\begin{array}{l}\text { Yeni değerleme firması tarafından hazırlanan değerleme raporlarında "Değerleme } \\
\text { işlemini olumsuz yönde etkileyen / sınırlayan faktörler" bölümünde, "Koronavirüs (Covid- } \\
\text { 19) olarak bilinen bulaşıı hastalık sebebiyle; Dünya Sağlık Örgütü ve Sağllk Bakanlığ } \\
\text { Koronavirüs Bilim Kurulu'nun önerileri doğrultusunda hareket edilerek saha ziyaretlerimiz } \\
\text { zorunlu olarak durdurulmuş olup, çalışmalarımı masa başından yürütülmü̈ştür. Bu nedenle, } \\
\text { konu gayrimenkul yerinde görülememiş ve ilgili Belediye'de imar dosyası incelemesi } \\
\text { yapılamamıştır." ibaresi yer almaktayken bazı raporlarda bu ibareye ek olarak "Konu, } \\
\text { gayrimenkulün mülkiyet yapısı açısından arsa pazarında ender olarak bulunan bir } \\
\text { gayrimenkul olması nedeni ile, dikkate alınan tahsisli arsa emsalleri yakın çevre dışı bölgeyi } \\
\text { de kapsayan daha geniş bir pazar alanından seçilmiştir." ibaresi yer almaktadır. }\end{array}$} \\
\hline
\end{tabular}




\begin{tabular}{|l|l|}
\hline $\begin{array}{l}\text { Covid-19 ile İlgili } \\
\text { Bilginin Geçtiği Bölüm }\end{array}$ & Dikkat Çekilen Hususlar \\
\hline $\begin{array}{l}\text { Covid-19 ile } \\
\text { İlgili } \\
\text { Açıklama }\end{array}$ & $\begin{array}{l}\text { Rapor tarihi itibari ile COVID-19 salgını nedeniyle Dünya Sağlık Örgütü tarafından } \\
\text { "pandemi" ilan edilmiştir. Mevcut durumun ekonomik koşullarda kısa vadede } \\
\text { turizm sektöründe daralmaya neden olacağı beklenmekle beraber, bu durum işletme } \\
\text { faaliyetleri ve sürekliliği üzerindeki etkisi belirsizdir. }\end{array}$ \\
\hline
\end{tabular}

\begin{tabular}{|c|c|c|c|}
\hline \multicolumn{3}{|c|}{ Firma: Kangal Termik Sant.Elek. A.Ş. } & $\begin{array}{l}\text { Bağımsız Denetçi: KPMG Bağımsız Denetim ve SMMM } \\
\text { A.Ş. }\end{array}$ \\
\hline \multicolumn{2}{|c|}{$\begin{array}{l}\text { Bağımsız Denetim } \\
\text { Görüsşü }\end{array}$} & \multicolumn{2}{|c|}{ Sınırlı Olumlu Görüş } \\
\hline \multicolumn{2}{|c|}{$\begin{array}{l}\text { Covid-19 ile İlgili } \\
\text { Bilginin Geçtiği Bölüm }\end{array}$} & \multicolumn{2}{|c|}{ Sınırlı Olumlu Görüşün Dayanağ1 } \\
\hline $\begin{array}{l}\text { Covid-19 ile } \\
\text { İlgili } \\
\text { Açıklama }\end{array}$ & \multicolumn{3}{|c|}{$\begin{array}{l}\text { Covid-19 salgınının ve yaşanan döviz kurundaki artışların işletmenin sürekliliğine } \\
\text { etkileri, bu dipnotlarda açıklanan olay veya şartlar ve diğger hususlarla birlikte } \\
\text { değerlendirildiğinde şirketin sürekliliğini devam ettirme kabiliyetine ilişkin ciddi } \\
\text { şüphe oluşturabilecek önemli belirsizliklerin mevcut olduğunu göstermektedir. }\end{array}$} \\
\hline
\end{tabular}

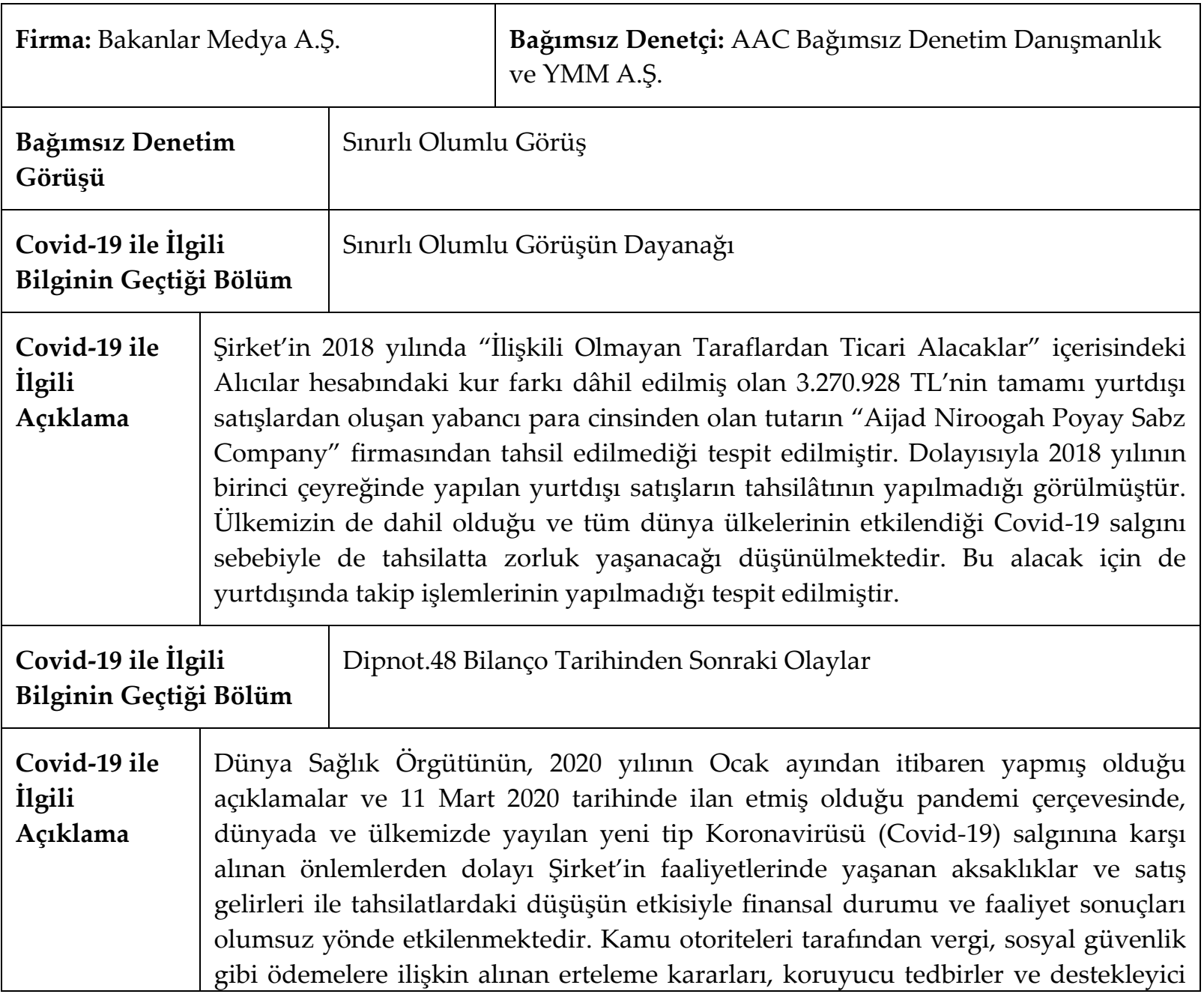




\begin{tabular}{|l|l|}
\hline & $\begin{array}{l}\text { uygulamalar ile bu sürecin olumsuz etkileri giderilmeye çalışılmaktadır. Bu salgının } \\
\text { ekonomik etkilerinin hesap dönemi sonu itibariyle belirsiz olması nedeniyle, Şirket'in } \\
\text { 31.12.2019 tarihli finansal tabloları üzerindeki etkileri tahmin edilememektedir. }\end{array}$ \\
\hline
\end{tabular}

\begin{tabular}{|l|l|l|}
\hline \multicolumn{2}{|l|}{ Firma: Halka açık olmayan yurtdışı merkezli bir A.Ş. } & Bağımsız Denetçi: Belirtilmesi istenmedi \\
\hline $\begin{array}{l}\text { Bağımsız Denetim } \\
\text { Görüşü }\end{array}$ & Olumlu Görüş \\
\hline $\begin{array}{l}\text { Covid-19 ile İlgili } \\
\text { Bilginin Geçtiği Bölüm }\end{array}$ & $\begin{array}{l}\text { Dipnotlar - 29: Raporlama Döneminden Sonraki Olaylar } \\
\text { Denetçi raporunda: İşletmenin sürekliliği ile ilgili önemli belirsizlik }\end{array}$ \\
\hline $\begin{array}{l}\text { Covid-19 ile } \\
\text { İlgili } \\
\text { Açıklama }\end{array}$ & $\begin{array}{l}\text { Türkiye'de iki aydır yaşanan Covid-19 salgını ile ilgili olaylar dikkate alındığında, } \\
\text { Covid-19 salgınının Türkiye tarım sektörü üzerindeki hâlihazırdaki ve yakın } \\
\text { gelecekteki potansiyel ekonomik etkilerinin Türkiye tarım sektöründe faaliyet } \\
\text { gösteren işletmelerin finansal durumu ve sürdürülebilirliği açısından olumlu olmasi } \\
\text { beklenebilir. } \\
\text { Bu bağlamda, Covid-19 salgınının ekonomik etkilerinin Şirket'in 2020 yılı finansal } \\
\text { durumu ve sürdürülebilirliği açısından olumlu olma ihtimali yüksektir. }\end{array}$ \\
\hline
\end{tabular}

\begin{tabular}{|l|l|l|}
\hline \multicolumn{2}{|l|}{ Firma: Desa Deri Sanayi ve Ticaret A.Ş. } & Bağımsız Denetçi: Birleşim Bağımsız Denetim A.Ş. \\
\hline $\begin{array}{l}\text { Bağımsız Denetim } \\
\text { Görüşü }\end{array}$ & 3 Aylık Ara Hesap Dönemine Ait Finansal Tabloların Denetimi \\
\hline $\begin{array}{l}\text { Covid-19 ile İlgili } \\
\text { Bilginin Geçtiği Bölüm }\end{array}$ & Dikkat Çekilen Hususlar \\
\hline $\begin{array}{l}\text { Covid-19 ile } \\
\text { İlgili } \\
\text { Açılama }\end{array}$ & $\begin{array}{l}\text { Dünya Sağlık Örgütü (WHO) tarafından } 2020 \text { yılı Mart ayında pandemi olarak ilan } \\
\text { edilen "Covid-19"un, insan sağlığının yanı sıra, üretim, ticaret ve ulaşım gibi birçok } \\
\text { alanda kısıtlayıcı etkileri bulunmaktadır. "Covid-19"'un tüm şirketlerin mali tabloları } \\
\text { üzerinde olumsuz etkisinin olacağ1 beklenmektedir. Covid-19 salgını nedeniyle, } \\
\text { Şirket 19 Mart 2020 tarihinde tüm satış mağazalarını kapatmış ve üretimi } \\
\text { durdurmuştur. 1.656 çalışan personelin 1.481'i için Nisan 2020 ayından itibaren } 3 \text { ay } \\
\text { süre ile kısa çalışma ödeneğine başvurulmuştur. (Not:25) }\end{array}$ \\
\hline
\end{tabular}




\section{SONUÇ VE TARTIŞMA}

Bu çalışmanın amacı; Covid-19 salgınının, bağımsız denetim süreci ve bağımsız denetçi raporu üzerindeki potansiyel etkilerini tartışarak, içinde bulunduğumuz salgın sürecinde denetim mesleği mensuplarının faaliyetlerini BDS'lere uygun bir şekilde yürütmelerine katkı sağlamaktır.

Bağımsız denetçi raporu örneklerinde görüldüğü gibi, 81 denetçi raporu arasından tespit edilen 10 adet denetçi raporunda Covid-19 ile ilgili olası veya potansiyel etkiler BDS'lerin gereklilikleri açısından değerlendirilmiştir. Söz konusu raporlarda Covid-19 ile ilgili olası veya potansiyel etkilere ilişkin açılamalara Görüş Vermekten Kaçınmanın Dayanağı, Diğer hususlar, İşletmenin Sürekliliğinin Değerlendirilmesi, Dikkat Çekilen Hususlar, Kilit Denetim Konuları, İşletmenin Sürekliliğiyle İlgili Önemli Belirsizlik, Sınırlı Olumlu Görüşün Dayanağı başlı̆̆ı altında yer verildiği görülmektedir.

Öte yandan bu örneklerde bağımsız denetim sürecinin son aşaması olan raporun düzenlenmesi aşamasında denetçilerin Covid-19 nedeniyle yaşanabilecek olumsuzlukları dikkate alarak sınırlı olumlu görüş verdikleri, hatta görüş vermekten kaçınma yoluna dahi gidebildikleri görülmektedir.

Şirketlerin raporlarında Covid-19 ile ilgili açıklamalara genellikle Bilanço Tarihinden Sonraki Olaylar başlığı altında yer verildiği görülmektedir.

Denetim süreci açısından diğer önemli bir husus salgın sürecinde fiziksel kontrollerin yapılmasının zorluğu nedeniyle yaşanabilecek yeterli ve uygun kanıt toplama sorunudur. Bu açıdan denetim riskinin artması söz konusudur.

Salgının, denetimin planlanması ve yürütülmesi, fiziksel kanıt toplama ve bağımsız denetim sürecine önemli etkileri olduğu görülmektedir. Bu nedenle bağımsız denetçilerin denetim riskini düşürmek için denetim sürecini bu duruma uygun bir yaklaşımla planlaması ve denetçi raporunu hazırlarken bu etkileri raporuna yansitmasi gerekir.

Özellikle Covid-19'un ekonomik etkilerinin ileriki dönemlerde de görülmeye devam edebileceği ihtimali düşünüldügünde denetim mesleği mensuplarının gerek denetimi yapılan şirketlerin bu konuda yapması gereken açıklamaları kontrol etmesi, gerekse denetim sürecini BDS'lere uygun yürütmesi açısından yukarıda tartışma konusu edilen hususları dikkate alması kaçınılmaz görünmektedir.

\section{KAYNAKÇA}

BDS 540 Muhasebe Tahminlerinin ve İlgili Açıklamaların Bağımsız Denetimi Standardı. (2019, 26 Aralık).

Resmi Gazete (Sayı: 30995 (4.Mükerrer)).

https://www.kgk.gov.tr/Portalv2Uploads/files/Duyurular/v2/BDS/BDS\%20540\%20kurum\%20sitesi. pdf (Erişim Tarihi: 20 Mayıs 2020).

BDS 560 Bilanço Tarihinden Sonraki Olaylar Standardı. (2017, 13 Aralık). Resmi Gazete (Sayı: 30269).

https://www.kgk.gov.tr/Portalv2Uploads/files/Duyurular/v2/BDS/BDSyeni11092019/BDS 560.pdf

(Erişim Tarihi: 21 Mayıs 2020).

BDS 570 İşletmenin Sürekliliği Standardı. (2017, 24 Mart). Resmi Gazete (Sayı: 30017 (M)).

https:/www.kgk.gov.tr/Portalv2Uploads/files/Duyurular/v2/BDS/BDSyeni11092019/BDS 570.pdf

(Erişim Tarihi: 22 Mayıs 2020).

BDS 701 Kilit Denetim Konularının Bağımsız Denetçi Raporunda Bildirilmesi Standardı. (2019, 31 Aralık).

Resmi Gazete (Sayı: 30995 (4.M)).

https://www.kgk.gov.tr/Portalv2Uploads/files/Duyurular/v2/BDS/BDS\%20701(2).pdf(Erişim Tarihi: 23 Mayis 2020).

BDS 705 Bağımsız Denetçi Raporunda Olumlu Görüş Dışında Bir Görüş Verilmesi Standardı. (2017, 24

Mart). Resmi Gazete (Sayı: 30017 (M)). 
B. A. Adana - M. Özbirecikli 12/2 (2020) 2080-2093

https://www.kgk.gov.tr/Portalv2Uploads/files/Duyurular/v2/BDS/BDSyeni11092019/BDS 705.pdf (Erişim Tarihi: 24 Mayıs 2020).

BDS 706 Bağımsız Denetçi Raporunda Yer Alan Dikkat Çekilen Hususlar ve Diğer Hususlar Paragrafları Standard1. (2017, 24 Mart). Resmi Gazete (Sayı: 30017 (M)).

https://www.kgk.gov.tr/Portalv2Uploads/files/Duyurular/v2/BDS/BDSyeni11092019/BDS 706.pdf (Erişim Tarihi: 25 Mayıs 2020).

COVID-19 Salgınının Yürütülen Bağımsız Denetimlere Etkisi. (2020, 31 Mart).

http://www.alomaliye.com/2020/03/31/covid-19-salgininin-yurutulen-bagimsiz-denetimlere-etkisi/ (Erişim Tarihi: 13 Mayıs 2020).

Selimoğlu, S., Özbirecikli, M., Uzay, Ş. (2019). Bağımsız Denetim. Ankara: Nobel Akademik Yayıncılık.

Türkiye Serbest Muhasebeci Mali Müşavirler ve Yeminli Mali Müşavirler Odaları Birliği (2020, Mart).

Koronavirüs Krizi: Finansal Raporlama ve Denetim Üzerindeki Sonuçları. TÜRMOB International, 52. https://www.turmob.org.tr/ebulten/TURMOBHaber/52/files/assets/basic-html/page-1.html

(Erişim Tarihi: 15 Mayıs 2020). 